\title{
Kerkgeskiedenis in ons teologiese opleiding:
}

\section{7-1956}

\author{
A D Pont \\ Universiteit van Pretoria
}

\begin{abstract}
Church history in our theological training: 1917-1956

After a short summary of the history of the founding of the Theological Faculty at the old Transvaal University College, attention is given to the Department of Church History. During the years 1921-1956 professor S P Engelbrecht built up this Department. Attention is given to his work as Church historian, his theological position is discussed and the result of his labours is given.
\end{abstract}

\section{INLEIDING}

In die Calvinistiese kerke wat uit die Kerkhervorming van die sestiende eeu voortgekom het, was die deeglike opleiding van bekwame dienaars van die Woord van die begin af 'n saak van groot gewig. Dit gebeur nie net omdat die Kerkhervorming sy begin by Martin Luther, 'n teologiese universiteits-professor, gehad het nie, maar veral omdat die regte verstaan van die Skrif sentraal in die hervormingsaksie gestaan het. Die Kerkhervorming van die sestiende eeu, in beide sy aanvanklike Duitse en Franse vorm, is gedra deur geleerde en gelowige manne bedrewe in hulle kennis van die grondtale van die Skrif, die leer en die geskiedenis van die kerk. Vandaar dat, van die begin af, 'n universitêre teologiese opleiding as 'n noodsaaklike komponent van die lewe en werk van die kerk beskou is (Henderson 1962:104). In die Nederlandse Hervormde Kerk word reeds in 1568 voorsiening gemaak vir die dienswerk van 'n teologiese professor (Pont 1981:78). In Nederland self, met die oprigting deur die Staten van Holland van 'n eerste universiteit te Leiden in 1575, is 
daar van die begin af ' $n$ teologiese fakulteit (Doekes 1917:24). Daar word dus begin met 'n universitêre opleiding van die predikante. Omdat Leiden egter 'n staatsuniversiteit is, was die kerk se seggenskap oor die aanstelling van professore en die inhoud en kwaliteit van die opleiding beperk. Dit het vanselfsprekend bepaalde probleme opgelewer veral as die denke van die kerk en dié van die kuratore van die universiteit in verskillende bane beweeg (Henderson 1962:112; Doekes 1917:25). Tog was dit so dat in Nederland 'n teologiese fakulteit noodsaaklik geag is vir die opleiding van predikante (Dankbaar 1978:180), omdat die kwaliteit van die verkondiging in en van die kerk so'n hoë voorkeur gehad het (Doekes 1917:30).

\section{DIE VOORSTADIUM VAN ONS TEOLOGIESE OPLEIDING}

As Jan van Riebeeck na Suid-Afrika kom, word sy nedersetting waardeer as 'n uitbreiding van die Kompanjiesbelange en, wat die kerk betref, word die kerk aan die Kaap gesien as 'n verlengstuk van die Nederlandse kerk. Die Kompanjiesbeleid waarvolgens die Kompanjie predikante moes voorsien om die Kompanjiesamptenare te bearbei, het 'n patroon geskep wat baie lank sou duur. Dit het vir die kerk in Suid-Afrika byna vanselfsprekend geword om of sy predikante uit Nederland te betrek of van sy lidmate na Nederland te laat gaan om daar teologie te studeer.

Die wegtrek van die Voortrekkers uit die Kaapkolonie om in die leë binnelande van Suidelike Afrika 'n vrye vaderland te vind, het hieraan nie veel verander nie. Daarom was die eerste Voortrekkerpredikante, Erasmus Smit en Daniel Lindley, altwee manne wat buite Suid-Afrika hulle teologiese opleiding ontvang het (Pont 1991:292-294, 298-299). Ná die koms van ds Dirk van der Hoff na die Oorvaalse was dit ook byna vanselfsprekend dat in die predikante-behoefte uit Nederland voorsien sou word. ' $n$ Verandering kom in hierdie beleid wanneer vanaf 1874 begin word om jong manne wat aan die Stellenbosse Kweekskool van die Kaapse kerk gestudeer het, na die Nederduitsch Hervormde Kerk te beroep (Pont 1955:111-113). Mede as gevolg hiervan vind die poging tot kerkvereniging in 1885 plaas. As die Hooggeregshof die handelinge van die Algemene Kerkvergadering wat in 1885 tot vereniging besluit het, in 1892 nietig verklaar, word daar weer teruggeval op die toevoer van Nederlandse predikante. Geleidelik het die behoefte aan 'n eie opleiding begin groei. Gedurende 1890 het ouderling $M J$ Willemse die saak van 'n eie opleiding in De Volksstem van 25 April 1890 aangeroer. Hoewel aan die saak aandag gegee is en dit moontlik gelyk het, het al die planne vanweë die Engelse oorlog van 1899-1902, tot niet gegaan. 


\section{3. 'N TEOLOGIESE OPLEIDING WORD MOONTLIK}

Ná die verwoesting van die oorlog was dit vir die Hervormde Kerk aanvanklik nie moontlik om aan iets anders aandag te gee as die reorganisasie van gemeentes en kerk nie. Buite die Hervormde Kerk om het daar egter belangrike dinge gebeur. Reeds op 17 Augustus 1903 het die Luitenant-goewerneur van Transvaal die Transvaal Technical Institute opgerig om verai aandag te gee aan die opleiding van mannekrag vir die goudmyne. Die Institute, wat in Johannesburg gevestig was, het reeds vroeg ook in Pretoria lesings aangebied vir 'n 'General Sertificate'. In 1906 is die Transvaal Technical Institute se naam verander na Transvaal University College wat sowel 'n akademiese as ' $n$ meer tegniese afdeling sou hê. Die eksaminerende liggaam sou die 'University of the Cape of Good Hope' wees (Ad Destinatum 1960:47).

Danksy die deurtastende optrede van generaal J C Smuts, die Koloniale Sekretaris vanaf Maart 1907, word die TUK in drie dele verdeel waarvan een deel in Pretoria gesetel is. Die lesings van die Pretoriase afdeling van die TUK het op $10 \mathrm{Fe}$ bruarie 1908 in Kya Rosa, Skinnerstraat 270 begin (Ad Destinatum 1960:13) en was breedweg gegroepeer rondom 'arts and science'. Uit die Pretoriase afdeling het in 1910 die selfstandige TUK, ná 'n besluit van die Transvaalse parlement, ontstaan en $£ 50000$ is bewillig om dit moontlik te maak (Ad Destinatum 1960:23-24). Die TUK was nou een van die sewe konstituerende kolleges van die University of the Cape of Good Hope.

Hierin het in 1916 verandering gekom toe die University of the Cape of Good Hope, wat tot op daardie stadium die eksaminerende universiteit was, vervang is deur die University of South Africa wat in Pretoria gesetel is (Kalender TUK 1918: 57). Die TUK het toe een van die ses samestellende kolleges van die Unie van Suid-Afrika geword waarin die kolleges veel groter selfstandigheid veral ten opsigte van eksaminering gekry het (Ad Destinatum 1960:41). Die feit dat die TUK in 1917 van 'n staatsinrigting na 'n staatsondersteunde inrigting verander is, het die onafhanklikheid verder bevestig.

Hierdie ontwikkelinge rondom die totstandkoming van 'n tersiêre onderwysinstansie in Pretoria, het vir die kerk nuwe moontlikhede laat oopgaan omdat van die begin die tale Latyn, Grieks en ook Hebreeus aan die TUK gedoseer is. Hoewel voornemende predikante van die kerk, ná die Engelse oorlog, na Nederland verwys is vir opleiding, het die gedagte aan 'n eie opleiding lewend gebly (Oberholzer 1967:17). Die eerste eie opleiding wat in die Hervormde Kerk onderneem is, was Prof P J Muller se opleiding van J J Prinsloo en J Kühn wat in 1906 begin het. In 1912, ná die totstandkoming van die TUK in Pretoria, besluit die Algemene Kerkvergadering dat met die owerheid onderhandel moes word oor die instelling van 'n 
leerstoel in die teologie aan dié inrigting. Daarvoor moes die Kuratorium, wat in 1909 in die lewe geroep is, hom veral beywer (Oberholzer 1967:19). Die Kuratorium het aanvanklik nie juis met hierdie taak gevorder nie, omdat daar ander sake in die kerklike lewe was wat al die andag gevra het (Oberholzer 1967:19). Dan rapporteer die Kuratorium aan die Algemene Kerkvergadering van 1916:

Het Kuratorium heeft verder de eer aan de Hoog Eerw Vergadering dit aan te bevelen: aangezien de wet op 't hoger onderwijs door het parlement is aangenomen, waardoor de mogelijkheid ontstaat dat te Pretoria een Universiteit zal worden opgericht, aan 't Kuratorium op te dragen met de Regering te overleggen of die genegen is een door onze kerk te benoemen en door haar te bezoldigen Hoogleraar in de Theologie aan te stellen.

Indien de Regering hiertoe genegen is, dan het Kuratorium op te dragen tot zulk' $n$ aanstelling over te gaan.

Indien de Regering evenwel op zulk 'n plan niet wil ingaan of 't vooruitzicht op een universiteit te Pretoria eerst in de verre toekomst kan worden verwezenlijkt, dan 't Kuratorium te machtigen in overleg te treden met het Kuratorium der kweekschool der Geref Kerk te Potchefstroom om vanwege onze Kerk aan die school een Hoogleraar te benoemen door ons gesalarieerd die in verbintenis met haar Hoogleraren onze studenten opleidt tot de Evangeliebediening.

(NHKA 1916a)

Uit hierdie rapport blyk dat die Kuratorium met die groot probleem van fondse geworstel het. Daar was op daardie stadium net nie die middele om uit eie krag 'n eie inrigting vir die opleiding van predikante te skep nie. Dit kon alleen gedoen word in samewerking met ander instansies en daarom word so 'n dubbelloop-voorstel aan die vergadering voorgelê.

'n Tweede saak wat hier na vore kom, is die feit dat die Kuratorium en die Algemene Kerkvergadering die moontlikheid van samewerking met die Gereformeerde Kerk se opleiding ook bespreek het. Dit was immers so dat die TUK 'n Engelstalige inrigting was (Kalender TUK:1919) met die meerderheid van die studente ook Engelstalig. Dit het die TUK se aantreklikheid vir baie mense in die kerk benadeel en die versoek om die opleiding na Potchefstroom te skuif is meer as een maal herhaal (NKHA 1916b:110; 1919:79, 134). Dit was nie net die Engelstaligheid van die TUK wat gehinder het nie, maar ook die feit dat die universitêre deel van die opleiding nie kerklik-dogmaties gebonde was nie. Die beswaar teen 'n skakeling met die Gereformeerde Teologiese Skool was weer die versigtigheid vir beïnvloeding van die kant van die Kuyper-teologie. Hoewel die Hervormde Kerk van meet 
af 'n konfessionele opleiding wou hê, het die Algemene Kerkvergadering die moontlikhede wat die TUK gebied het, verkies al was dit aanvanklik nie presies wat die Hervormde Kerk begeer het nie.

Die skepping van ' $n$ teologiese fakulteit aan die TUK is nie alleen bespreek deur die Algemene Kerkvergadering nie maar het ook in die kringe van die TUK beplanning uitgelok. Reeds op 10 Julie 1916 skryf Dr F V Engelenburg, een van die raadslede, aan die Chairman of the Council TUC (in NHKA Argief):

There are branches of theology, being purely scientific, which can be taught to pupils of any sect. Other branches require tuition according to dogma. If a chair was established for say philosophy of religion... ecclesiastical history, NT Greek and Hebrew, pupils of diverging creeds could follow the professor's lessons....

Engelenburg stel dus 'n oop fakulteit voor waar die kerklike dogma nie 'n voorveronderstelling by die onderwys sal wees nie. Hierdie voorstel het instemming van die kant van die Raad gekry. Daarop het die Raad die Nederduitsch Hervormde Kerk asook die Nederduitsch Hervormde of Gereformeerde Kerk, die Presbiteriaanse en Wesleyaanse kerke gevra om met die Raad in gesprek te tree oor die stigting van 'n teologiese fakulteit (Engelenburg 1916; Van Belkum 1917). Op die basis van Engelenburg se skrywe aan die Raad van die TUK is op 7 Desember 1916 ' $n$ vergadering van verteenwoordigers van die Raad van die TUK met verskillende kerkmanne gehou, onder andere ds H S Bosman (NH of G Kerk), ds Jac van Belkum en dr J H J A Greyvenstein (NHKA), Rev E MacMillan (Presbiteriaanse kerk) en Rev A Burnet (Wesleyaanse kerk) (NHKA 1916a). Daar is veral gewag gemaak van die besluite van die University College of North Wales wat ook 'n teologiese fakulteit sonder enige kerklike binding gevestig het. Daar is toe eenstemmigheid bereik oor die instelling van so 'n Fakulteit wat, met die begin daarvan, opleiding sou kon verskaf aan voornemende predikante van die Hervormde, Verenigde en Presbiteriaanse kerke (NHKA 1916c).

Die beplanning het ' $n$ bepaalde aansluiting gevind by die opvattings in die Nederduitsch Hervormde Kerk wat reeds in sy Kerkwet van 1914 (art 79) 'n teologiese kursus in die vooruitsig gestel het wat vir die grootste deel geskoei was op die Nederlandse universiteitsreëling van 1876 (Aalders 1990:94-97).

Die Kuratorium het op sy vergadering van 25 Januarie 1917 finaal die beplanning goedgekeur (vgl ook Oberholzer 1967:19) en terselfdertyd is dr J H J A Greyvenstein, toe predikant van Pretoria en ook lid van die Kommissie van die Algemene Kerkvergadering, as hoogleraar vanweë die Nederduitsch Hervormde Kerk benoem. Aanvanklik is hy slegs deur die Hervormde Kerk gesalarieer, maar dit het verander toe hy deur die Raad van die TUK as lektor benoem is. 
As gevolg van besluite van die Raad is op 1 April 1917 met die werksaamhede in die Fakulteit Teologie begin. Aanvanklik is 'n vyfjarige BA en BD kursus ingestel. Na die driejarige BA-kursus, waar die klem gelê is op die studie van Grieks (3 jaar), Hebreeus ( 2 jaar) en Latyn ( 1 jaar), het die tweejarige BD-kursus gevolg waar die studie van die Ou- en Nuwe-Testamentiese Wetenskappe dieselfde klem as Kerkgeskiedenis gekry het. Dit het beteken dat die spesifiek kerklike vakke buite die BD-kurrikulum geval en addisioneel deur die kerklike dosente behartig moes word. Die kerklike vakke is op die kerklike proponentseksamen geëksamineer: Onder hierdie vakke het getel die Geskiedenis van die kerk, Kerkreg van die kerk, Dogmatiek en ander vakke.

Hiermee is die duplex ordo wat vir die teologie gegeld het in die meeste Europese universiteite, ook vir die Pretoriase opleiding aanvaar. Die feit dat hierdie soort opleiding aan die Nederlandse Rijksuniversiteite gegeld het, het seker ook 'n rol gespeel in die kerk se aanvaarding van hierdie bedeling. Tog het die aanvaarding van die duplex ordo by die Hervormde Kerk ontevredenheid uitgelok en in 1919 is daar weer op die Algemene Kerkvergadering geargumenteer dat die opleiding eerder na Potchefstroom verplaas moes word.

Twee argumente het hier 'n rol gespeel: Die een was dat die TUK 'n engelstalige inrigting was en dat dit dus 'n kultuur-en lewensopvatting adem wat anders was en selfs vyandig teenoor dié van die Afrikaner gestaan het. Die ander argument was dat daar nie so-iets soos 'n 'neutrale teologiese opleiding' kan bestaan soos dit aan die TUK gevestig is nie. Teologie, so is geoordeel, is kerklike teologie of dit is een of ander vorm van godsdienswetenskap (vgl NHKA 1919:79-80). Dit was opvallend dat diegene wat gepleit het vir 'n kerklike opleiding van mening was dat die regte struktuur 'n soort waarborg sal wees vir regte teologie, terwyl 'n struktuur nooit werklik so 'n finale waarborg kan wees nie. Hoewel in die argument toegegee is dat die TUK nie Christelik-nasionaal is nie (NHKA 1919:88) is geargumenteer dat die opleiding by die TUK die beste is wat op daardie stadium verkry kon word, want 'n kweekskool, los van 'n universiteit, is nie aanvaarbaar geag nie. Daarby was daar ook bedenkings oor 'n te noue saamgaan, in 'n teologiese opleiding, met die Gereformeerde Kerk wat al meer op Kuyper en die Vrije Universiteit van Amsterdam georiënteer was (NHKA 1919:85-86). Greyvenstein het geargumenteer dat die struktuur nie die waarborg kan wees van 'n deeglike kerklik-bepaalde, selfs konfessionele opleiding nie. Die kerk moet, deur middel van sy vergaderings, self toesien dat die inhoud en die kwaliteit van die opleiding voldoen aan die vereistes wat die kerk ten opsigte van die leer en lewe van sy voornemende predikante stel. Daarby het hy gestel (NHKA 1919:88): 
We zijn in Pretoria geen vreemdelingen; we worden als gelijken behandeld; ik heb zitting in de senaat; zij raadplegen mij; het lijkt mij of die twee broeders denken dat alleen Ds MacMillan en niet ik, invloed heeft op onze studenten. Ze vergeten, dat ik met hen omga als een vader met zijn kinders. Er is geen gevaar voor mislukking....

Greyvenstein se argument kom daarop neer dat die oortuigde kerkman-teoloog selfs in 'n neutrale struktuur nog die regte onderwys en opleiding kan aanbied. Waarskynlik ook om aan besware tegemoet te kom, het hy saam met S P Engelbrecht in 1924 'n Teologiese Studentevereniging gestig om so die band tussen die dosente en die studente te verstewig. Op dié manier het Greyvenstein 'n positiewe invloed uitgeoefen, sodat hy by die studente as Vadertjie bekend gestaan het. In dié saak is hy deur Engelbrecht bygestaan en is die studie aan die Fakulteit algaande gestuur in die rigting van 'n kerklike, dit wil sê konfessioneel-bepaalde Fakulteit wat teologie in die kerk en ten behoewe van die kerk beoefen volgens die aanvaarde riglyne wat die kerk gestel het (NHKA, Kerkwet 1989:Art I, II).

\section{DIE FAKULTEIT TEOLOGIE WORD 'N WERKLIKHEID}

Op 1 April 1917 het die groot oomblik vir die Nederduitsch Hervormde Kerk aangebreek toe die Fakulteit met sy werksaamhede kon begin. Naas J H J A Greyvenstein is E MacMillan van die Presbiteriaanse Kerk op 'n deeltydse basis aangestel. Saam het hulle die tweejarige BD-kursus aangebied met hulp van veral prof A C Paterson wat Latyn en Hebreeus doseer het en ook met die Ou Testament-lesings behulpsaam was. Greyvenstein, wat in hoofsaak aangestel is vir die Nuwe-Testamentiese Wetenskap, het in die periode 1917-1920 ook Kerk- en Dogmengeskiedenis en Kerkreg naas Dogmatiek onder sy sorg geneem.

MacMillan, wat aanvanklik aangestel is vir die Ou-Tetamentiese Wetenskap, het hom later veral op die dosering van Apologetics toegelê. Hoewel hy aan die Fakulteit aangestel is omdat verwag is dat die Presbiteriane hulle opleiding ook aan die TUK sou vestig, het daar niks van gekom nie. Hy het dus nooit die vrag van addisionele doseerwerk vir kerklike vakke gedra nie.

In 1922 is die tweejarige BD-kursus uitgebrei na 'n driejarige kursus. Dit was ook moontlik omdat dr S P Engelbrecht, nadat hy in 1920 aan die Rijksuniversiteit van Utrecht gepromoveer het, van die begin van 1921 aangestel is om Kerkgeskiedenis te behartig. Die Fakulteit is in 1926 versterk met die aanstelling van dr B Gemser uit Nederland in die plek van prof A C Paterson wat bedank het. Daar was op daardie stadium vier leerstoele in die Fakulteit en hulle het die hele kurrikulum en die bykomende kerklike vakke behartig. 
Hierdie struktuur van die onderrig het so bly geld tot in 1935 toe die Nederduitsch Hervormde Kerk 'n nuwe ooreenkoms met die Universiteit van Pretoria, die opvolger van die ou TUK, gesluit het. Die veranderinge het moontlik geword nadat prof MacMillan in 1933 bedank het om al sy aandag aan sy werk in die Oxfordgroep te gee. Met sy bedanking het die Nederduitsch Hervormde of Gereformeerde Kerk na vore gekom met die gedagte dat sy leerstoel deur 'n dosent uit die kerk gevul sou word. Op dié stadium geld die duplex ordo nog volledig.

Nog in 1934 stel die Fakulteit Teologie in 'n skrywe aan die Raad (UP 1934):

Die bogenoemde vakke wat die Fakulteit doseer, is almal suiwer universitêre vakke, wat 'n integrerende deel uitmaak van die encyclopedie van wetenskappe en sonder welke die universitêre onderwys as geheel onvolledig sou wees. Geen van die genoemde vakke dra 'n kerklike karakter nie; geen daarvan word ook vanuit 'n kerklike oogpunt gedoseer deur die huidige leerkragte nie. Vakke vir die kerklike praktyk soos Dogmatiek en Praktiese Teologie...maak geen deel uit van die leerplan nie en word nie geëksamineer vir die BD-graad nie.

Hierdie duplex ordo is formeel bestendig deur die eerste skriftelike ooreenkoms wat die Hervormde Kerk op 15 Junie 1934 met die Universiteit aangegaan het om die verhouding wat tot op daardie stadium op 'n mondelinge afspraak berus het, behoorlik te omskrywe (vgl Ad Destinatum 1960:165). Volgens hierdie ooreenkoms sou die Nederduitsch Hervormde Kerk steeds drie van 'n moontlike ses professorate in die Fakulteit vul. Die Universiteit sou, wat die drie professorate betref, verplig wees om, in die geval van 'n vakature, een uit 'n drietal kandidate wat die kerk voorlê, moes aanstel. Om die voorreg te behou, moes die kerk'n vasgestelde jaarlikse skenking aan die Universiteit maak om daarmee die Fakulteit in stand te hou.

Met die toetrede van die Nederduitsch Hervormde of Gereformeerde Kerk tot die Fakulteit Teologie aan die Universiteit, wat begin het met die aanstelling van prof G M Pellissier op 1 Januarie 1935, het die situasie verander. Aangesien die kerk, kragtens sy ooreenkoms van 1934 kennis gegee het dat die Hervormde studente nie Pellissier se lesings sou bywoon nie, het die moontlikheid om 'n gesamentlike teologiese opleiding te vestig, verdwyn (Ad Destinatum 1960:171). Dan ontstaan die gedagte om eerder aan elke kerk outonomie in sy opleiding te gee en so ontstaan die een Fakulteit met twee parallelle fakulteitsafdelings. In die daaropvolgende kontrak tussen die Hervormde Kerk en die Universiteit om dit te reël, word vir die eerste maal van departemente gepraat. Vantevore is sle is na 'n leerstoel verwys, maar nou word dit professorate wat terselfdertyd departementshoofde met administratiewe take is. In die kontrak van 1935 word Kerkgeskiedenis dan opgeneem in 
die Departement Geskiedenis van die Christendom wat in senioriteit net ná die Departement Ou- en Nuwe-Testamentiese Wetenskappe kom (NHKA Argief).

Met hierdie reëling word dan sonder meer van die duplex ordo afgestap en word die vroeëre kerklike vakke 'n vanselfsprekende onderdeel van die teologiese kurrikulum. Terselfdertyd is met die aangaan van die 1935 -kontrak 'n vierde departement ingestel wat Dogmatiek en Godsdienswetenskap genoem is. Met die 1935 kontrak word elke fakulteitsafdeling 'n volledige kerklik-bepaalde opleiding waar die professore volledig gebonde bly aan dieselfde ondernemings ten opsigte van die leer en die orde van die kerk as die dienaars van die Woord in hulle kerke. Behalwe dat die fakulteitsafdeling met twee departemente uitgebrei is vanaf 1935 , het die basiese struktuur van die afdeling en sy invoeging in die struktuur van die Universiteit daarna dieselfde gebly.

\section{DIE LEERSTOEL EN DEPARTEMENT KERKGESKIEDENIS}

Met die aanvang van die werksaamhede van die Fakulteit in 1917, word daar nog nie voorsiening gemaak vir 'n aparte leerstoel vir Kerkgeskiedenis nie. Tog vorm dit 'n vaste onderdeel van die kurrikulum. Daar is 'n tweejarige studie van die algemene Kerkgeskiedenis vereis waarin die eerste studiejaar die periode 70-1517 en die tweede jaar die periode 1517 tot die moderne tyd, behandel het. Dan was daar 'n eenjarige kursus Dogmengeskiedenis (Kalender TUK 1920:135). 'n Eenjarige kursus, 'geschiedenis van het Gereformeerd Kerkrecht', is ook aangebied. Vanweë die duplex ordo wat dan geld, is vir die proponentseksamen 'n studie van die geskiedenis en die Kerkreg van die kerk vereis. Hoewel dit moeilik is om dit te presiseer, kan waarskynlik aangeneem word dat Greyvenstein vir die eerste drie jaar (1917-1920) vir die onderrig en eksaminering van die Kerkgeskiedenis en Kerkreg verantwoordelik was. Dit is interessant om daarop te let dat Kerkgeskiedenis van die begin af as 'n noodsaaklike deel van die BD- en kerklike eksamen beskou is en dat dit dieselfde gewig as die Bybelwetenskappe in die BD-kursus gehad het.

Die onderrig en wetenskaplike studie van die geskiedenis van die kerk en sy leer, is op 'n vaste voet geplaas toe S P Engelbrecht van die begin van 1921 in die Fakulteit aangestel is. Hy is vir die aanstelling deur die Kerk voorgedra en deur die Raad van die TUK aangestel kragtens die destyds geldende ooreenkoms (NHKA 1928:72). Die Kuratorium het op 15 April 1921 (NHKA 1921) sy opdrag as volg omskryf: '...dat Dr Engelbrecht sal les geven in kerkgeschiedenis, kerkrecht, dogmatiek, geschiedenis en philosophie van den godsdienst en Bybelsch theologie.'

Dit was 'n geweldige wye opdrag wat miskien vanselfsprekend was as in ag geneem word dat op daardie stadium net drie dosente die hele teologiese opleiding 
moes behartig. Hoewel soms gebruik gemaak is van dosente uit die Fakulteit Lettere om bepaalde kursusse aan te bied, het die verantwoordelikheid daarvoor op die skouers van die teologiese dosente gerus (Kalender TUK 1923).

As S P Engelbrecht in 1921 diens aanvaar by die teologiese opleiding, is hy die eerste seun uit die Nederduitsch Hervormde Kerk wat 'n opdrag kry om mee te werk aan die opleiding van predikante vir die kerk. Kerklik was hy daarvoor goed toegerus, want hy was afkomstig uit een van die gesiene Voortrekkerfamihes in die Oorvaalse (Pont 1987:256-258). Vanweë die feit dat sy vader, G J Engelbrecht wat op kerklike en politieke vlak 'n belangrike rol gespeel het, in 1901 sneuwel en vanweë generaal Kitchener se barbaarse oorlogsbeleid, is die familie ná die oorlog heeltemal verarm. Dit bring mee dat sy skoolopleiding, wat buitendien deur die oorlog vertraag is, nie dadelik op gang kon kom nie. Uiteindelik het ds Jac van Belkum hom oor Engelbrecht ontferm, en ná sy skoolopleiding te Heidelberg en 'n periode van studie te Potchefstroom, vertrek hy in 1913 na Nederland om daar teologie te studeer. Op 2 Julie 1920 sluit hy sy studie aan die Rijksuniversiteit te Utrecht af met sy promosie tot Doctor Theologiae op grond van sy proefskrif: Geschiedenis van de Nederduitsche Hervormde Kerk van Zuid-Afrika. Sedert de Groote Trek tot aan de eerste annexatie van Transvaal. Eerste stuk.

Sy sewejarige verblyf in Nederland het nie net tot Engelbrecht se vorming bygedra nie, maar ook 'n bepaalde stempel op hom geplaas. Die feit dat hy met 'n Nederlandse dame, M J H Gerritsen getroud is net voor sy terugkeer na sy vaderland, het meegebring dat ook sy huislike lewe 'n duidelike Nederlandse stempel gedra het. Dit alles het beteken dat Engelbrecht vir die grootste deel van sy lewe geywer het om die kerklike en kulturele bande tussen Nederland en die noordelike Afrikaner te verstewig (Gravemeyer 1961:40-51). Daarin het hy aangesluit by die beleid van die kerk en ook die beleid wat deur pres S J P Kruger gevoer is om deur middel van skakeling met Nederland 'n kerklike, kulturele en politieke teëwig te vind teen die opdringende Engelse invloede in Suid-Afrika.

As Engelbrecht in 1921 met sy doseerwerk begin, staan hy voor groot uitdagings. Nie alleen moes hy die grondslae vir die doseer van die Kerkgeskiedenis lê nie, maar hy moes dit doen aan 'n universiteit wat nog net begin het en waar 'n goeie en doeltreffende biblioteek nog nie bestaan het nie. Daarby was daar ook nog nie so-iets soos 'n kerklike argief nie. Hoewel vir die vakgebied van die algemene Kerkgeskiedenis daar seker voldoende handboeke en studiemateriaal was, moes hy die geskiedenis so aanbied dat dit sy relevansie met die Suid-Afrikaanse situasie sou behou. Terselfdertyd moes hy lesings gee oor die geskiedenis van die Nederduitsch Hervormde Kerk. Behalwe sy proefskrif en A D W Wolmarans se Historiese Feiten was daar geen wetenskaplik-verantwoorde gepubliseerde materiaal van belang wat 
hy kon gebruik nie. Dit het beteken dat hy in alles moes voorsien, terwyl hy terselfdertyd ook nog ' $n$ rits ander vakke moes behartig. Daarby het Engelbrecht, om aan die Fakulteit Teologie wat aanvanklik nie groot getalle studente getrek het nie, 'n breër staanplek aan die universiteit te gee, ook lesings oor die Transvaalse geskiedenis in die Departement Geskiedenis van die Fakulteit Lettere, gegee. Daardie lesings en die invloed wat daar van hom uitgegaan het, het daartoe bygedra om 'n bepaalde verstaan van die geskiedenis te yk. Dit was een van die maniere waarop Engelbrecht se invloed baie wyer as net sy kerk uitgekring het. Sy werkvermoë en sy totale betrokkenheid by sy opdrag, gekoppel aan sy groot liefde vir sy kerk en volk, het as die spoorslag gedien wat hom in staat gestel het om die struikelblokke te oorkom.

\section{ENGELBRECHT AS HISTORIKUS}

As Engelbrecht se geskiedskrywing, sy werk as historikus, beoordeel word, is dit belangrik om daarop te let dat hy die uitgangspunte en die riglyne vir sy siening van die geskiedenis reeds gevorm het vóor sy proefskrif in 1920 verskyn het. Reeds as agtienjarige het hy in 'n brief wat in De Hervormer (1909-10-15) verskyn het, blyke gegee dat hy instem met wat in die breë genoem kan word die 'Hervormde verstaan en interpretasie van die Voortrekker- en Transvaalse geskiedenis'. As dit gestel word, dan kan daarop gewys word dat die wortels vir daardie verstaan van die geskiedenis in die Hervormde Kerk self lê. Die vroegste vorm daarvan waarna verwys kan word, is die herderlike skrywe van die Algemene Kerkvergadering van 1855, Eene stem uit Mooirivier. Daarnaas kan verwys word na die notule van die verenigingskommissie van 1882 (Pont 1955:140). Daarby kan seker gereken word M J Goddefroy se De Kerkkwestie, niet een leer - maar een levenskwestie van 1889 en A D W Wolmarans se Kerkhistoriese Feiten I en II uit die jare 1919-1920. (Ander kleiner pogings om die geskiedenis op te teken, word nie hier vermeld nie.) Dié kerkhistoriese visie het weer aansluiting gevind, in die breë, by die vroeë pogings om die Transvaalse geskiedenis te beskrywe. Hier kan verwys word na die werk van C J N du Plessis, J H Malan, J Stuart, E J P Jorissen en W J Leyds. Hoewel hierdie werke nog nie wetenskaplike historiese studies is nie, is dit uitdrukking van ' $n$ bepaalde visie van die geskiedenis en 'n poging om die gebeure uit die verlede relevant te maak vir die hede.

Die eerste maal wat Engelbrecht sy verstaan van die geskiedenis na vore bring, is wanneer hy in 1917 in die tydskrif Stemmen voor waarheid en vrede 'n kritiese bespreking wy aan die werk van C Spoelstra van 1915, Het kerkelijk en godsdienstig leven der Boeren na den Grooten Trek. 
In sy bespreking van Spoelstra se werk kom die verskil tussen die Hervormde verstaan van die geskiedenis en dié van die Kaapse (NG) historici duidelik na vore. Hier gaan dit onder andere om die vraag of die Voortrekkers regmatig 'n selfstandige kerklike organisasie ná hulle vertrek uit die Kaapkolonie opgerig het waarvan die Hervormde Kerk in die Oorvaalse 'n voortsetting was, soos die Hervormde verstaan van die geskiedenis dit sien. Daarteenoor het die Kaapse historici gestel dat die Voortrekkers deurentyd lidmate van die Kaapse kerk gebly het en dat die verwerping van die inlywing van die Transvaalse gemeentes in die Kaapse kerklike struktuur 'n afskeiding is. Dit bring mee dat die 'stigting' van die Nederduitsch Hervormde Kerk as selfstandige kerk en die datum waarop dit geskied het in daardie historiese skool nogal heelwat probleme opwerp. Die ander verskilpunte word nie hier opgesom nie.

In sy bespreking van Spoelstra se werk blyk dit dat Engelbrecht 'n baie goeie kennis van die bronne-materiaal van die geskiedenis het en dat hy geen vreemdeling in die argiewe is nie (Engelbrecht 1917:29). In sy proefskrif en in die daaropvolgende uitbreiding daarvan in 1925 en in die tweede en derde uitgawes van sy Geskiedenis van die Nederduitsch Hervormde Kerk van Afrika in 1936 en 1953, het Engelbrecht deur sorgvuldige en omvattende navorsing die Hervormde verstaan van die geskiedenis wetenskaplik gefundeer. Daarmee het hy nie net die grondlegger geword van die wetenskaplike navorsing en geskiedskrywing in die ruimte van die Nederduitsch Hervormde Kerk nie, maar het hy ook 'die eer en betekenis van ons verlede' verwoord (Rautenbach 1961:39).

Engelbrecht se geskiedskrywing was op sorgvuldige bron- en argiefnavorsing gebou met die doel om aan die hand van dié primêre materiaal 'n beeld van die verlede aan te bied. Dit het meegebring dat hy mettergaan 'n uitnemende kenner van die argiefmateriaal was en ook'n ywerige versamelaar van historiese dokumente en ander materiaal. Sy onvermoeibare speurtogte na historiese bronne-materiaal het beteken dat hy ook die grondlegger geword het van die Hervormde Argief wat, vanweë die rykdom aan materiaal, een van die uitnemende kerkargiewe in die noorde van ons land is.

In sy kerkgeskiedskrywing word dit gou duidelik dat die saak van die Hervormde Kerk vir Engelbrecht van groot gewig was. Oor die wyse waarop hy die verlede verstaan en voorgestel het, het prof $\mathrm{C}$ H Rautenbach op Engelbrecht se sewentigste verjaarsdag nog dié kommentaar gelewer (Rautenbach 1961:39):

Al word beweer dat die enigste les wat die geskiedenis leer is dat die geskiedenis geen les leer nie, en al word vermaan dat die geskiedenis nie eintlik 'n wapen mag wees vir verweer of aanval nie, het dit tog steeds in die geaardheid van die jubilaris (S P Engelbrecht - A D P) 
gelê om die geskiedenis 'n les te laat leer en om 'n bruikbare geweer te wees vir aanval en verdediging ook op gebiede buitekant die kerklike bestaan. Dit was van besondere betekenis vir die Afrikaner in 'n tydperk van strewe na behoud van eie identiteit en toenemende geestelike, met begrip van kulturele, selfontplooiing. Dit was juis die toedrag van sake sedert die driejarige oorlog.

Rautenbach se siening dat die aard van Engelbrecht se geskiedskrywing ook beïnvloed is deur die beleërde posisie van die kerk in die dekades ná die Engelse oorlog, is sekerlik korrek. Die opmerklike is egter dat, hoewel daar oor die aard van sy geskiedskrywing heelwat gesê is, die vaste, argivale basis van sy geskiedskrywing nooit werklik aangetas kon word nie. In sy dispuut met G D Scholtz in 1957, het Engelbrecht weer 'n bewys gegee van sy kennis, nie net van die verlede nie, maar veral van die argivale bronne waarop hy sy geskiedskrywing gebaseer het (Engelbrecht 1957a:137-179; 1957b:95-157). Dit is opvallend dat Engelbrecht, wanneer hy in so 'n polemiek betrokke was, steeds in staat was om historiese materiaal aan te haal wat sy teenstander, na sy mening, nie verdiskonteer het nie (vgl Engelbrecht 1957a:32; 1957b:156). Juis in sy byna verbasende kennis van die boustene van die geskiedenis het Engelbrecht se krag as historikus gelê. Daaraan kan sy besondere kennis van die familiegeskiedenisse van die Voortrekker en Transvaalse families gekoppel word. Dit het hom nie net in staat gestel om interne samehange in die Afrikanervolk te verstaan nie, maar daarby het sy publikasie van talle familiegeskiedenisse in die Almanak baie daartoe bygedra om die historiese bewussyn van die Hervormde lidmate op te skerp. Oor die betekenis van Engelbrecht se geskiedskrywing het ds A J G Oosthuizen hom as volg uitgelaat:

Hy (Engelbrecht - A D P) het bewys dat die Ned Herv Kerk nie alleen die historiese voortsetting van die kerk in Suid-Afrika is nie, maar ook van die tradisie en die karakter. Dat dit die bolwerk teen vreemde invloede was, en die volk teen verwildering op geestelik gebied 'n skuiling gebied het, is deur hom met bewyse aangetoon. Die werk van prof Engelbrecht het meegebring dat die kerk uiteindelik die swaard kon neerlê, en met altwee hande bou. Die gevoel van eiewaardigheid het rus en kalmte gebring. Met rustige versekerdheid kon die kerk sy gang gaan....

(Oosthuizen 1946:80)

In sy geskiedskrywing het Engelbrecht homself voortdurend skerp afgegrens teen die Kaapse kerk wat vir hom, enigsins ongenuanseerd, die draer was van die Metodisme, andersyds het hy hom sterk verset teen die opvatting wat deur die Kaapse 
historici en kerklui gepopulariseer is dat die Nederduitsch Hervormde Kerk liberaal sou wees. In die derde plek het hy hom afgegrens teen die Neo-calvinisme van Kuyper. Die opvallende in sy geskiedskrywing is dat hy weinig aandag gee aan 'n omskrywing van die teologiese rigting van die lidmate en predikante van sy kerk. Hoewel toegegee moet word dat dit, vanweë die gebrek aan voldoende materiaal, baie moeilik is om daaroor 'n finale uitspraak te maak, is dit tog 'n leemte in sy kerkhistoriese werk. Waarskynlik het dit saamgehang met die feit dat hy, na die gebruik van die laat-negentiende eeu in Europa, 'n te sterk onderskeid tussen Kerkgeskiedenis en Dogmengeskiedenis gemaak het.

\section{ENGELBRECHT SE TEOLOGIESE POSISIE}

Juis in dié lig gesien, is dit miskien tog noodsaaklik om 'n poging aan te wend om Engelbrecht se eie teologiese posisie te bepaal. Dit kan miskien die maklikste gedoen word deur te let op die dogmenhistoriese artikels wat hy gepubliseer het. Die vakgebied van die Dogmengeskiedenis wat Engelbrecht vanaf 1921 hanteer het, het hom 'n aantal interessante en belangrike artikels laat skryf. Hierdie artikels, waar die klem op die historiese geval het, het sy merkwaardige belesenheid en wye kennis duidelik geillustreer (vgl Engelbrecht 1943/1944a:32vv); dit is egter, om dit net in die verbygaan te noem, nie vreemd vir enigiemand wat ooit in sy studeerkamer met sy uitgebreide biblioteek was nie. Hy het nie net elke boek wat hy gehad het, geken nie, maar ook presies geweet waar elke boek te vinde was en wat die belangrikste argumente van die skrywer was.

Uit sy dogmenhistoriese arbeid kan 'n poging aangewend word om Engelbrecht se teologiese posisie te bepaal. Daarmee kan begin word deur daarop te wys dat hy in die jare 1913-1920 aan die Utrechtse fakulteit studeer het. As hy daar aankom, is hy reeds 22 jaar oud, wat daaraan gewyt moet word dat hy eers ná die Engelse oorlog met sy skoolopleiding kon begin. Sy skoolopleiding het hy in Heidelberg voltooi waar hy so min of meer onder die sorg van ds Jac van Belkum was, een van die goed-ortodokse predikante van die kerk. By Van Belkum het Engelbrecht ongetwyfeld in aanraking gekom met sy grotendeels konfessionele teologie en met daardie opvattings is hy na Europa. Hoewel die Utrechtse teologiese fakulteit aan die einde van die negentiende en die begin van die twintigste eeu beset is deur professore wat die etiese rigting toegedaan was (Wiegeraad 1991:45), vind daar vanaf 1903 'n geleidelike verskuiwing plaas. Dit het begin met die aanstelling van $\mathrm{H}$ Visscher in 1903 deur die destydse verantwoordelike minister, dr A Kuyper. Daarop volg in 1908 die aanstelling van J A C van Leeuwen vir Nuwe-Testamentiese Wetenskap en in 1912 van A Noordtzij vir Ou-Testamentiese Wetenskap. In 1913 word H Th 
Obbink, wat as regs-eties aangedui word, aangestel. Daarmee het die Fakulteit 'n duidelike konfessionele karakter gekry wat saamgehang het met die aanstellingsbeleid wat deur Kuyper gevoer is (Wiegeraad 1991:49). Dan verteenwoordig die kerkhistorikus S D van Veen en Obbink miskien nog die etiese rigting maar dan nie meer in die styl van die groot voormanne van die rigting nie (Aalders 1990:15-16).

Hieruit kan afgelei word dat Engelbrecht se opleiding grotendeels 'n konfessionele kleur gehad het wat vir hom nie vreemd sou gewees het nie. Hoewel hy by Van Veen studeer het, is dit duidelik dat by Engelbrecht die kenmerkende etiese opvattings nie inslag gevind het nie. Dat Obbink as sy promotor opgetree het, is in 'n sekere sin toevallig, omdat Van Veen, weens siekte dit nie kon waarneem nie (Engelbrecht 1920:vii). Engelbrecht se hoë waardering vir Obbink het eerder op die persoonlike vlak as op teologiese verwantskap berus (Engelbrecht 1948:48). Dit blyk ook uit Engelbrecht se dogmenhistoriese studies, waar hy hom enersyds steeds afgrens teen die Arminianisme, die Metodisme en die Subjektiewe Teologie aan die een kant en aan die ander kant teen die Neo-calvinisme wat swaar leun op die ontwikkeling van die na-Calvyn-ortodoksie in die sewentiende eeu.

Uit Engelbrecht se dogmenhistoriese studies, waarvan die meeste in die Hervormde Teologiese Studies gepubliseer is, blyk ook dat hy nie belangstelling vir die tipies-etiese klemtone in die teologie het nie. Die betrokke groep studies handel oor die Nederlandse Geloofsbelydenis en die Heidelbergse Kategismus as simboliese geskrifte (Engelbrecht 1943/1944b:80-95; 1943/1944c:160-173), die bekendste Hervormde konfessies (Engelbrecht 1944/1945a:145-157; 1946a:41-45) oor die Westminster Konfessie (Engelbrecht 1947/1948:61-73) en dan oor erfsonde en doop (Engelbrecht 1944/1945b:171-173) en die onsterflikheid van die siel (Engelbrecht 1951/1952:106-111). Die opvallende in hierdie studie is nie alleen die historiese noukeurigheid nie, maar ook die feit dat sy beoordelingsnorm veral die werk van Joh Calvyn, die sestiende-eeuse reformatoriese vadere en die konfessies self is. Op belangrike punte wys hy die etiese opvattings af, soos oor die geloofsekerheid (Engelbrecht 1943/1944b:82) waar hy die reformatoriese opvatting duidelik na vore bring (vgl hieroor o a Aalders 1990:108). Dit is ook opvallend dat hy nêrens die groot etiese denkers soos De la Saussaye, Valeton, Van Dijk en Gunning aanhaal nie, maar dat hy, naas die Reformatoriese geskrifte, eerder verwys na Kohlbrugge, Goddefroy en ander verteenwoordigers van die Objektiewe Teologie.

Teenoor die teologie van Kuyper en Bavinck grens hy hom ook af, enersyds in sy artikel Kuyper en John Milton (Engelbrecht 1946b:46-53) en dan breedvoeriger in sy geskrif van 1945, Neo-calvinisme: Ontwikkeling en afwyking. Dan het hy reeds vroeër, in 1929, 'n pamflet gepubliseer: Wat is Kalvinisme? 'n Tydvraag. Interessant is dat hy in hierdie pamflet swaar leun op prof $H$ Visscher se verwerping van die 
Neo-calvinisme. Dit is miskien nie so vreemd nie, want Visscher het nogal 'n sterk invloed in die Utrechtse fakulteit en op die Afrikaners wat daar studeer het, uitgeoefen (Wiegeraad 1991:64). Dit is waarskynlik aan Visscher se blywende invloed te danke dat Engelbrecht in sy teologiese werk steeds weer terugverwys na Calvyn en die hervormde konfessies van die sestiende eeu.

Die polemiek waarvan Neo-calvinisme: Ontwikkeling en afwyking 'n vrug was, het ontstaan vanweë die bedenkings wat ds J V Coetzee uitgespreek het oor 'n reeks artikels oor die Nederlandse Geloofsbelydenis, artikels 1-9, wat Engelbrecht in Die Hervormer van Oktober 1942 tot Julie 1943 gepubliseer het. Dit is interessant om vas te stel dat Engelbrecht in sy verweer hom hoofsaakhk beroep op konfessioneelortodokse Nederlandse teoloë soos Hoedemaker, De Wilde, Kromsigt, Oorthuys en Haitjema. Engelbrecht beklemtoon dan dat Kuyper se teologie 'n ontwikkeling en afwyking van Calvyn se teologie is en dat hy hom eerder tuis voel by die teologiese denke van die bogenoemdes. Hieruit word dit wel duidelik dat Engelbrecht geen waardering vir die Subjektiewe Teologie gehad het nie en op grond daarvan kan met sekerheid gesê word dat hy nie as 'n etiese teoloog aangedui kan word nie. Teologies was Engelbrecht tuis in die konfessionele kring, hoewel hy met sy hoë waardering vir Kohlbrugge tog 'n eie posisie daar ingeneem het.

\section{ENGELBRECHT AS DOSENT}

In 1946 het ds A J G Oosthuizen van Engelbrecht geskrywe:

In sy hoedanigheid as professor, was hy ook altyd iemand van wie inspirasie uitgegaan het. Hy loop altyd oor van geesdrif en wek dan ook by sy studente belangstelling en geesdrif vir die Kerk op. Niemand kan met hom in aanraking kom sonder om onder die indruk te kom van die feit dat hy net een groot liefde ken en dit is sy liefde vir die Ned Herv Kerk.

(Oosthuizen 1946:82)

Dit is 'n waar woord en 'n baie groot deel van Engelbrecht se groot invloed in die kerk was juis hieraan te danke.

Wat die lesings wat hy gegee het betref, was dit vir Engelbrecht belangrik dat sy studente 'n goeie, oorsigtelike kennis moes hê van die Algemene Kerkgeskiedenis. Hier het hy veral die klem op die geskiedenis van die sestiende-eeuse Kerkhervorming gelê en dan verder aandag gegee aan die historiese verloop van die geskiedenis. Hy het hier nie veel detailstudie verwag nie en vir hom was byvoorbeeld die oorsigtelike werk van Berkhof, Geschiedenis der kerk waarvan die eerste uitgawe in 1941 verskyn het, voldoende as 'n handboek. In sy lesings het Engelbrecht baie 
moeite gedoen om die geskiedenis as 'n stuk lewende verlede aan sy studente voor te hou en daarom het hy dikwels allerlei wetenswaardighede en anekdotes oor belangrike historiese figure meegedeel.

Langs die Algemene Kerkgeskiedenis het hy veral ruimte gemaak vir Nederlandse kerkgeskiedenis. Enersyds het hy hieraan aandag gegee, omdat die invloede uit die Europese wêreld van die sewentiende tot die negentiende eeu grotendeels via Nederland na die Afrikaner deurgewerk het. Daarom was dit vir hom van belang dat die Nederlandse verwerking daarvan begryp sou word. Andersyds het dit saamgehang met sy oortuiging dat veral die noordelike Afrikaner steeds aansluiting by Nederland moes soek om so staande te kan bly teen die Engelse invloede. Daarom was die Nederlandse Hervormde Kerk vir hom sonder meer 'die moederkerk' en het hy steeds sy persoonlike en vriendskapsbande met Nederlanders, waarvan sommige uit sy studentedae dateer het, onderhou. Dié opvattings het hy egter in die vroeë sestigerjare skerp hersien toe ook die Nederlandse kerk in die greep van die sosialistiese ideologie gekom het en hom by die vyande van die Afrikanervolk en sy kerk geskaar het. Hoe belangrik hy die verbondenheid met Nederland beskou het, blyk ook daaruit dat hy baie moeite gedoen het om die Nederlandse Kultuur-historiese Instituut aan die Universiteit te vestig (Ploeger 1946a:92).

Daarnaas het Engelbrecht oorsigtelik lesings gegee oor die Dogmengeskiedenis en die Kerkreg, maar die meeste aandag en toegespitste belangstelling het hy aan die Suid-Afrikaanse Kerkgeskiedenis en daarin die geskiedenis van die Nederduitsch Hervormde Kerk gegee. Dit het ook oorheersend in sy wetenskaplike werk gestaan en in sy lesings hieroor was sy hele oorgawe daaraan vir elkeen duidelik. Hoewel, in 'n tyd toe diktaat-lesings aan die orde was, Engelbrecht nie baie aantekeninge laat afskryf het nie, was sy lesings juis toegespits op die verstaan van die geskiedenis, die vermelding van bronne-materiaal en die beklemtoning van die belangrikheid van detail-gegewens.

Vir baie jare het Engelbrecht ook Dogmatiek-lesings gegee. Daar het hy in hoofsaak volstaan met die bespreking van P J Muller se Handboek der Dogmatiek wat uit 1908 dateer het. Aan die einde van sy termyn as dosent in die vak het hy veral G C van Niftrik se Kleine Dogmatiek bespreek. Hier was dit opvallend dat sy verwysingsraamwerk in hoofsaak Calvyn en naas hom Luther en Zwingli en dan veral die Hervormde Belydenisskrifte uit die sestiende eeu was. Dit is seker nie vreemd nie dat selfs in sy lesings oor die dogmatiek sy historiese belangstelling oorheersend was.

Die oorheersende indruk van Engelbrecht as dosent is sy intense betrokkenheid by die kerk - sy geskiedenis, sy wel en weë. Daarom kon hy, meer as een maal, in die lesingkamer uitvoerig kommentaar lewer op die doen en late in en van die kerk. 
Vanuit die geskiedenis het hy dan beoordeel en rigting aangedui. Op dié manier het hy aan sy studente baie geleer van die lewenstyl en lewensorde van die kerk.

Engelbrecht het in 1921 begin met die vestiging en uitbou van die vak Kerkgeskiedenis in die Fakulteit Teologie. By sy aftrede in 1956 het hy 'n gevestigde departement wat aansien in die wetenskaplike wêreld gehad het, nagelaat. Op dié vakgebied het hy nie net sy geskiedenis nie, maar 'n hele reeks van insiggewende en belangwekkende gemeentegeskiedenisse, artikels en ander publikasies nagelaat (vgl Ploeger 1946b:210vv). Op die vakgebied van die staatkundige geskiedenis was daar sy imposante Burgers-biografie wat in $1946 \mathrm{nog}$, op aanbeveling van generaal J C Smuts, in Engels vertaal is. 'n Hele reeks van artikels op hierdie vakgebied het bygedra dat hy gesien is as een van die belangrikste figure in die sogenaamde 'noordelike skool' van historici. Ook buite die kring van kerk en Universiteit is hy geëer vir sy bydraes, soos blyk uit sy lidmaatskap van verskillende buitelandse vakverenigings (Ploeger 1946a:92).

\section{AFSLUITENDE OPMERKINGS}

Aan die Universiteit het hy sorg gedra dat die teologiese biblioteek sterk uitgebou is en deur sy toedoen het die Universiteitsbiblioteek prof $\mathrm{J}$ du Plessis van Stellenbosch se omvangryke biblioteek verkry terwyl prof dr J W Pont op sy versoek ook belangrike skenking gemaak het, onder andere die Weimar Ausgabe van Luther se werk.

In die kerk het hy die grondlegger geword van die omvangryke Kerkargief en na sy aftrede het hy nog 'n paar jaar daar gewerk om die materiaal te orden. Die Argiefbiblioteek, wat van groot waarde vir die navorser is, is rondom sy biblioteek gebou. Die museum, wat sy naam dra, het as nukleus die versameling van oudhede wat hy opgebou het.

Engelbrecht het in die 35 jaar wat hy aan die Fakulteit Teologie verbonde was, nie alleen werk van hoë wetenskaplike waarde verrig nie, hy het hom nie alleen beywer vir die behoud van die Fakulteit in die periode 1924-1925 en weer in 1928 nie, maar hy het veral 'n stempel geplaas op die predikante wat aan die Fakulteit studeer het. Daardeur en deur sy ander werk het hy 'n wesenlike bydrae gelewer om die geskiedenis van kerk en volk as 'n lewende werklikheid in die aandag te hou. Daarmee het hy die Kerk nie net gedien nie maar ook gebou. 


\section{Literatuurverwysings}

Aalders, M J 1990. Ethisch tusschen 1870 en 1920. Kampen: Kok.

Ad Destinatum 1960. Gedenkboek van die Universiteit van Pretoria. Johannesburg: Voortrekkerpers.

Dankbaar, W F 1978. Hervormers en humanisten: Een bundel opstellen. Amsterdam: Ton Bolland.

Doekes, G 1917. Het kerkelijk doctorenambt. Kampen: Kok.

Engelbrecht, S P 1917. Een histories-krities onderzoek histories krities onderzocht. Stemmen voor Waarheid en Vrede. Oordruk.

-.- 1920. Geschiedenis van de Nederduitsch Henormde Kerk in Zuid-Afrika. Eerste stuk. Amsterdam: De Bussy.

-.. 1943/1944a. Die nederdaling van Christus na die hel uit 'n dogmenhistoriese oogpunt besien. HTS 1, 32-41.

--1943/1944b. Die Ned Geloofsbelydenis as simboliese geskrif. HTS 1, 80-95.

-.- 1943/1944c. Die Heidelbergse Kategismus as kerklike simbool. HTS 1, 160173.

-.- 1944/1945a. Die Hervormde konfessies. HTS 2, 145-157.

--- 1944/1945b. Die Roomse, Lutherse en Hervormde beskouings oor die erfsonde en die doop. HTS 2, 171-173.

-- 1946a. Die hervormde konfessies. HTS 3, 41-45.

-.- 1946b. Dr A Kuyper en John Milton. HTS 3, 46-53.

-.- 1947/1948. Die Westminsterse konfessie. HTS 4, 61-73.

-.- 1948. In memoriam Prof dr H Th Obbink. HTS 5, 48.

-.- 1951/1952. Die onsterflikheid van die menslike siel. HTS 8, 106-111.

--- 1957a. Dr G D Scholtz se geskiedenis van die NH of Geref Kerk. HTS 12, 137 179.

-- 1957b. Nogmaals Dr G D Scholtz se geskiedenis van die NH of Geref Kerk. HTS 13, 95-157.

Engelenburg, F V 1916. Brief aan die Chairman of the Council TUC 10 Julie 1916. Pretoria: NHKA.

Gravemeyer, K H E 1961. Een dankbare herinnering aan wat prof dr S P Engelbrecht voor de goede betrekkingen tussen Zuid-Afrika en Nederland gedaan heeft. HTS 17/2-4, 40-51.

Henderson, R W 1962. The teaching office in the reformed tradition. Philadelphia: The Westminster Press.

Nederduitsch Hervormde Kerk van Afrika 1916. Notule van die Kuratorium 24 April 1916a. Pretoria: NHKA.

-.- 1916b. Notule van die Algemene Kerkvergadering 1916. Pretoria: NHKA. 
Nederduitsch Hervormde Kerk van Afrika 1916c. Minutes of the meeting of the Education Functions Committee, 7th December 1916. Pretoria: NHKA.

--- 1919. Notule van die Algemene Kerkvergadering 1919. Pretoria: NHKA.

--- 1921. Notule van die Kuratorium. Pretoria: NHKA.

--- 1928. Notule van die Algemene Kerkvergadering 1928. Pretoria: NHKA.

--- 1989. Kerkwet en bepalings. Pretoria: NHKA.

Oberholzer, J P 1967. Na vyftig jaar: 1917-1930, in Gedenkalbum van die Teologiese Fakulteit (Afd A) van die Universiteit van Pretoria. Krugersdorp: NHW Pers.

Oosthuizen, A J G 1946. Die betekenis van prof dr S P Engelbrecht vir kerk en volk. HTS 3, 79-82.

Ploeger, J 1946a. Die betekenis van prof dr S P Engelbrecht as historikus. HTS 3, 83-93.

--- 1946b. Lys van geskrifte van prof dr S P Engelbrecht. HTS 3, 210-213.

Pont, A D 1955. Nicolaas Jacobus van Warmelo 1835-1892. Utrecht: Kemink \& Zoon.

--- 1981. Die historiese agtengronde van ons kerklike reg, Deel 1. Pretoria: HAUM.

--- 1987. Engelbrecht, Stephanus Petrus, in Beyers, C J (red), Suid-Afrikaanse Biografiese Woordeboek, Deel V. Pretoria: RGN.

-.- 1991. Die historiese agtengronde van ons kerklike reg, Deel 2. Pretoria: KITAL.

Rautenbach, C H 1961. Professor dr S P Engelbrecht en die geestelike kultuur van die Afrikaner. HTS 17/2-4, 39-40.

Universiteit van Pretoria 1918, 1919, 1920, 1923. Transvaalse Universiteits-Kollege Kalender. Pretoria: Wallachs \& Co.

--- 1934. Skrywe van Fakulteit Teologie aan die Raad: Memorandum insake die Fakulteit van Godgeleerdheid aan die UP. Pretoria: NHKA.

Van Belkum, J 1917. Brief in De Volksstem, 26 Junie 1917.

Van Jaarsveld, F A sa. Soek hom.

Wiegeraad, B J 1991. Hugo Visscher 1864-1947: Een calvinist op eigen houtje. Leiden: Uitgeverij J J Groen \& Zoon. 